\title{
Pinealni parenhimni tumor intermedijarnog stupnja diferencijacije - prikaz slučaja
} Pineal parenchymal tumor of intermediate differentiation - case report

\author{
Dora Gašparini ${ }^{1 *}$, Nives Jonjić ${ }^{2}$, Dinko Štimac ${ }^{3}$, Andrea Dekanić $^{2}$
}

${ }^{1}$ Medicinski fakultet, Sveučilište u Rijeci, Rijeka

${ }^{2}$ Zavod za patologiju, Medicinski fakultet, Sveučilište u Rijeci, Rijeka

${ }^{3}$ Klinika za neurokirurgiju, Klinički bolnički centar Rijeka, Rijeka

\begin{abstract}
Sažetak. Cilj: Prikazati slučaj pacijentice s pinealnim parenhimnim tumorom intermedijarnog stupnja diferencijacije gradus II, s naglaskom na patohistološku dijagnozu ovog kliničkog entiteta. Prikaz slučaja: Tridesetosmogodišnja pacijentica primljena je na Kliniku za neurokirurgiju Kliničkog bolničkog centra Rijeka radi operativnog liječenja ciste pinealne regije. Osnovni i jedini simptomi bile su glavobolje unatrag četiri godine. Magnetska rezonancija mozga ukazivala je na cističnu tvorbu pinealne regije. Učinjena je osteoklastična subokcipitalna medijana kraniotomija s ekstirpacijom ciste pinealne regije te je bioptički uzorak poslan na patohistološku analizu. Histološki je utvrđeno oskudno tkivo mozga infiltrirano umjereno celularnim tumorskim tkivom građenim od difuzno raspoređenih, malih uniformnih stanica oskudne citoplazme s tendencijom stvaranja perivaskularnih acelularnih područja i diskretnim pineocitomatoznim rozetama. Jezgre tumorskih stanica bile su ovalne, monomorfnog izgleda s mjestimičnom blagom polimorfijom. Mitotska aktivnost bila je niska i iznosila je manje od 0,5\%. U bioptičkom uzorku bilo je nekoliko manjih žarišta kalcifikacije, ali bez prisutnosti nekroze. Imunohistokemijska analiza pokazala je izrazitu difuznu obojenost na neuron specifičnu enolazu (engl. neuron-specific enolase, NSE) i znakove neuroendokrine diferencijacije, o čemu svjedoči snažna difuzna obojenost na sinaptofizin. Na temelju histološke slike i imunohistokemijskog profila zaključeno je da pregledani materijal predstavlja pinealni parenhimni tumor intermedijarnog stupnja diferencijacije - WHO gradus II. Pacijentica se nakon operacije osjećala dobro i otpuštena je na kućno liječenje. Zaključci: Jedino ispravno postavljena patohistološka dijagnoza može dovesti do odgovarajućeg izbora terapije $i$ ispravnog kliničkog pristupa pacijentu $s$ pinealnim parenhimnim tumorom intermedijarnog stupnja diferencijacije. Daljnja molekularna istraživanja bila bi korisna patologu u postavljanju standarda i izradi smjernica koje bi pomogle u postavljanju točne dijagnoze.
\end{abstract}

Ključne riječi: dijagnostika; patologija; pinealom; tumori mozga; tumori središnjeg živčanog sustava

Abstract. Aim: To report a case of a patient with the pineal parenchymal tumor of intermediate differentiation grade II, with emphasis on histopathological diagnosis of this clinical entity. Case report: A 30-year-old patient was admitted at the Clinic for Neurosurgery at the Clinical Hospital Centre Rijeka in order to surgically remove a cyst in the pineal region. The only and main symptoms were headaches in the past four years. Magnetic resonance was performed to visualize the pineal cyst. Osteoclastic suboccipital median craniotomy with extirpation of the cyst had been done and the biopsy specimen was sent to the Pathology Department of the Clinical Hospital Centre Rijeka. Histologically, the tissue of the brain was infiltrated by a moderately cellular tumor tissue consisting of diffusely distributed small uniform cells with scarce cytoplasms and with the tendency to form perivascular acellular areas with discrete pineocytomatous rosettes. Nuclei of the tumor cells were oval and monomorphic with an occasional mild polymorphism. Mitotic activity was low and measured less than $0.5 \%$. The biopsy specimen included several smaller foci of calcification without the presence of necrosis.

Napomena: Prikaz slučaja izrađen je u sklopu radionice „Kako napisati dobar prikaz slučaja?“, u organizaciji časopisa Medicina Fluminensis Medicinskog fakulteta Sveučilišta u Rijeci i Znanstvenog odbora svih studenata (ZOSS) Medicinskog fakulteta Sveučilišta u Rijeci (voditeljica: doc. dr. sc. Nina Pereza, dr. med.).

http://hrcak.srce.hr/medicina 
Immunohistochemistry showed strong diffuse positivity for neuron-specific enolase and synaptophysin, which suggested neuroendocrine differentiation. According to the histological findings and immunohistochemistry profile, the pineal parenchymal tumor of intermediate differentiation - WHO gradus II has been diagnosed. The patient was feeling well after the operation and had been dismissed for further home treatment. Conclusions: Only precisely determined histopathological diagnosis will result in adequate choice of therapy and accurate clinical approach to any patient with this type of tumor. Further molecular research needs to be conducted in order to form standardized guidelines which would help in process of confirming the exact diagnosis.

Key words: brain neoplasms; central nervous system neoplasms; diagnosis; pathology; pinealoma

\section{UVOD}

Tumori pinealne regije rijetki su i čine od 0,4 do $1 \%$ intrakranijalnih tumora u američkoj i europskoj populaciji, dok su nešto više incidencije u Japanu, gdje čine $3,2 \%$ intrakranijalnih tumora ${ }^{1}$. U njih ubrajamo: pineocitom, pinealni parenhimni tumor intermedijarnog stupnja diferencijacije, pineoblastom i papilarni tumor pinealne regije ${ }^{2}$. Osim tumora parenhima pinealne žlijezde (14 $27 \%$ ) u pinealnoj regiji mogu se pojaviti i ostale novotvorine kao što su: zametni tumori (germinomi i teratomi, $40 \%$ ) te nešto rjeđe astrocitomi, meningeomi i pinealne ciste ${ }^{3-4}$. Histološka klasifikacija tumora središnjeg živčanog sustava Svjetske zdravstvene organizacije iz 2016. godine tumore pinealne žlijezde dijeli na: pineocitom (gradus I), pinealni parenhimni tumor intermedijarnog stupnja diferencijacije (gradus II ili III), papilarni tumor pinealne regije (gradus II ili III) i pineoblastom (gradus IV) ${ }^{2}$. Pinealni parenhimni tumor intermedijarnog stupnja diferencijacije (engl. pineal parenchymal tumor of intermediate differentiation, PPTID) najčešće se pojavljuje u žena između trećeg i šestog desetljeća života ${ }^{5-6}$. U zlatnoj sredini između pineocitoma i pineoblastoma, dvaju ekstrema u diferencijaciji tumora pinealne žlijezde, nalazi se PPTID, najproblematičnija kategorija koja se zbog složene patohistološke slike ponekad pogrešno tumači kao pineocitom ili pineoblastom atipične prezentacije, što onemogućuje ispravan odabir odgovarajuće terapije i određivanje točne incidencije ovih tumora. S obzirom na morfološki izgled i biološko ponašanje, PPTID se prema Svjetskoj zdravstvenoj organizaciji dijeli u dvije kategorije; gradus II i gradus $1 \mathrm{II}^{7-8}$. U radu je prikazan slučaj pacijentice s pinealnim parenhimnim tumorom intermedijarnog stupnja diferencijacije gradus II, s naglaskom na patohistološku dijagnozu ovog kliničkog entiteta.

\section{PRIKAZ SLUČAJA}

Tridesetosmogodišnja pacijentica primljena je na Kliniku za neurokirurgiju Kliničkog bolničkog centra Rijeka radi operativnog liječenja ciste pinealne regije. Osnovni i jedini simptomi bile su glavobolje unatrag četiri godine. Druge je tegobe pacijentica negirala. Učinjena je magnetska rezonancija mozga (engl. magnetic resonance, MR) koja je ukazivala na cističnu tvorbu pinealne regije. Dotad pacijentica nije teže bolovala. Učinjena je osteoklastična subokcipitalna medijana kraniotomija s ekstirpacijom ciste pinealne regije te je bioptički uzorak poslan na patohistološku analizu. Na Zavodu za patologiju Kliničkog bolničkog centra Rijeka primljeno je više komadića smećkasto žućkastog tkiva koji su ukupno mjerili $18 \times 15 \times 3$ $\mathrm{mm}$. Uzorak tkiva fiksiran je u $10 \%$-tnom puferiranom formalinu, rutinski je obrađen i uklopljen u parafin, a zatim je uslijedilo rezanje i bojenje hematoksilin-eozinom i retikulinom. Od imunohistokemijskih bojenja primijenjena su primarna protutijela usmjerena na glijalni fibrilarni kiseli protein (engl. glial fibrillary acidic protein, GFAP), sinaptofizin i neuron specifičnu enolazu (engl. neuron specific enolase, NSE) i Ki-67 za procjenu proliferacijskog indeksa tumorskih stanica. Histološki je utvrđeno oskudno tkivo mozga infiltrirano umjereno celularnim tumorskim tkivom građenim od difuzno raspoređenih, malih uniformnih stanica oskudne citoplazme (slika 1A) s tendencijom stvaranja perivaskularnih acelularnih područja (slika 1B) i diskretnim pineocitomatoznim rozetama. Jezgre tumorskih stanica bile su ovalne, monomorfnog izgleda s mjestimičnom blagom polimorfijom. Mitotska aktivnost (proliferacijski indeks Ki-67) bila je niska i iznosila je manje od 0,5 \% (slika 1C). U bioptičkom uzorku bilo je nekoliko manjih žarišta kalcifikacije, ali bez prisutnosti nekroze (slika 1D). Imunohistokemijska analiza pokazala je izrazitu difuznu obojenost na NSE (slika 1E) i znakove neuroendokrine diferencijacije, o čemu svjedoči 


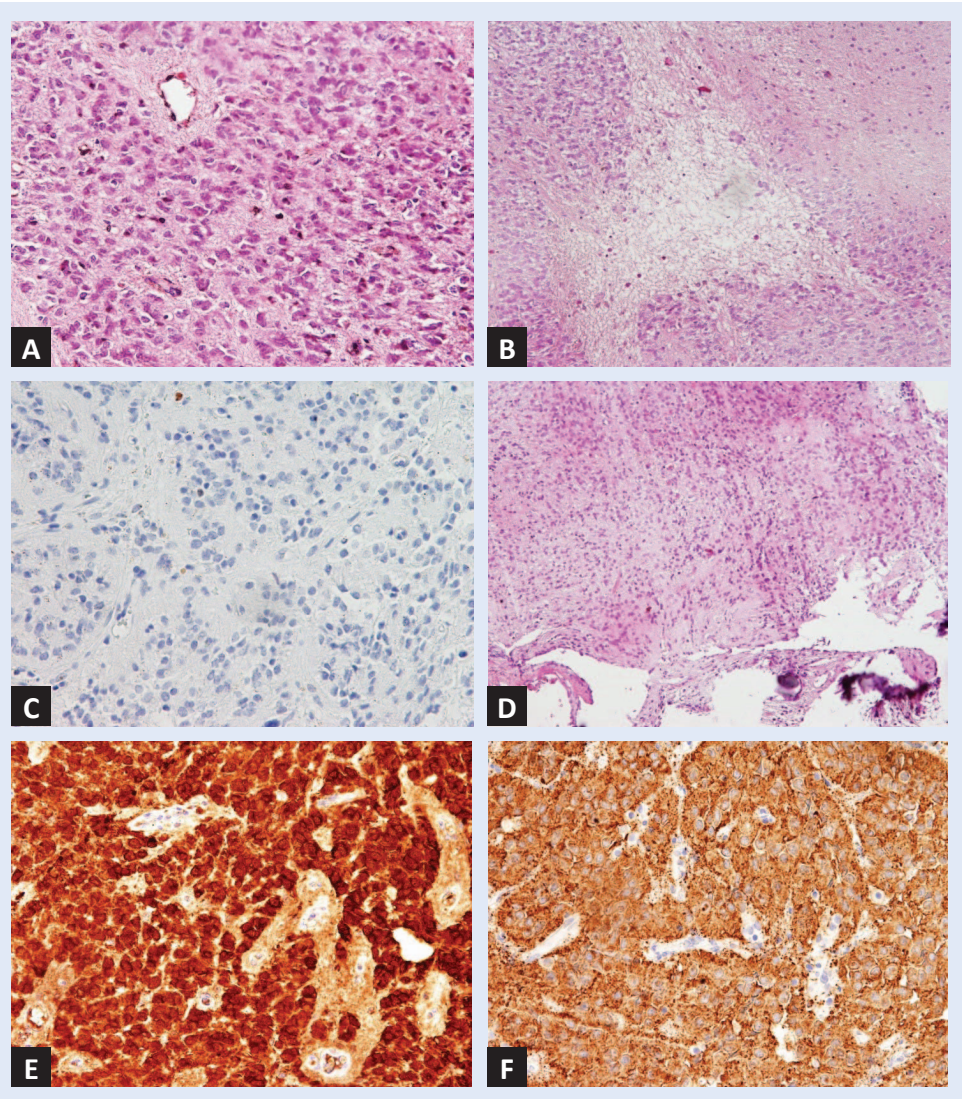

Slika 1. Histološke i imunohistokemijske osobitosti pinealnog parenhimalnog tumora intermedijarne diferencijacije. (A) Uzorak hipercelularnog tumorskog tkiva difuznog rasta koji se sastoji od uniformnih stanica (HE, $\times 200$ ).

(B) Perivaskularni prostori bez jezgara koji sadržavaju fini fibrilarni materijal $(\mathrm{HE}, \times 100)$. (C) Tumorske stanice pokazuju mali broj jezgara pozitivnih na Ki-67 bojenje ( $\times 200)$. (D) Žarišna područja kalcifikacije u tumorskom tkivu (HE, $\times 100)$. (E) Tumorske stanice prikazuju snažnu difuznu obojenost na NSE bojenje ( $\times 200)$. (F) Difuzna ekspresija sinaptofizina u tumorskom tkivu $(\times 200)$. ostalih pinealnih tumora, ali i tumora zametnih stanica, koji se obično isključuju temeljem odsustva povišenih vrijednosti humanog korionskog gonadotropina ( $\beta$-hCG) i alfa-fetoproteina (AFP). Tumorske stanice u PPTID-u generalno pokazuju umjerenu nuklearnu polimorfijiu i manje citoplazme od vrlo dobro diferenciranih tumorskih stanica pineocitoma. Formiranje karakterističnih pineocitomatoznih rozeta ne potvrđuje nužno PPTID, zbog moguće pojavnosti ovih struktura i u drugim morfološkim tipovima tumora ${ }^{8-9}$. Postoji mogućnost da su pojedini pineocitomi skloni recidivu zapravo neprepoznati PPTID ${ }^{10}$. Diferencijalno dijagnostički u obzir dolazi i pineoblastom s nakupinama slabo diferenciranih malih plavih stanica $s$ učestalim mitozama, apoptotičnim tjelešcima, tzv. sljepljivanjem ili mouldingom jezgara i nekrozama ${ }^{9}$. Nakon potvrde dijagnoze PPTID-a slijedi njegova daljnja karakterizacija u jedan od tri morfološka podtipa: (1) uzorak lobuliranog tumorskog rasta $\mathrm{s}$ dobrom prokrvljenošću (endocrine-like), (2) uzorak difuznog tumorskog rasta (nalik oligodendrogliomu ili neurocitomu) te (3) prijelazni oblik s područjima lobulirane i/ili difuzne arhitekture i $s$ područjima dobro oblikovanih pineocitomatoznih rozeta (engl. pineocytoma-like) ${ }^{11}$.

U našem slučaju radilo se o mladoj ženi s četverogodišnjim glavoboljama kojoj je slikovnom metodom dokazana cistična tvorba pinealne regije. Diferencijalno dijagnostički razmatrana je kao pinealna cista i intraventrikularni tumor. Histološkim i imunohistokemijskim pregledom isključili su se navedeni entiteti, te je definitivna dijagnoza upućivala na pinealni parenhimni tumor intermedijarnog stupnja diferencijacije.

Krajnji i vjerojatno najvažniji korak u dijagnostici PPTID-a je određivanje patološkog gradusa koji može biti niski (gradus II ili PPTID malih stanica) ili visoki (gradus III ili PPTID velikih stanica), a upravo to definira odabir terapije, tijek bolesti i preživljenje pacijenta s ovim tumorom ${ }^{9}$. PPTID niskog gradusa sastoji se od prijelaznog, lobuliranog ili difuznog uzorka rasta tumorskih stanica malenih uniformnih jezgara oskudne citoplazme i neprimjetnih jezgrica. Tumor snažno eksprimira pozitivitet na neurofilamentne proteine, a stanice pokazuju niski Ki-67 proliferacijski indeks (< $6 \%$ ). PPTID visokog gradusa predstavlja lobulirani ili di- 
fuzni uzorak rasta tumorskih stanica s pleomorfnim jezgrama vezikularnog izgleda i obilnim citoplazmama, stromom nalik na neuropil uz odsustvo pineocytoma-like regija te stanica visokog proliferacijskog indeksa (> 6\%) i ograničenog pozitiviteta na neurofilamentne markere. Tumor ponekad sadržava žarišta nekroze, leptomeningealnu infiltraciju i vaskularnu proliferaciju ${ }^{7-9}$. Moguće je da su PPTID malih stanica i PPTID velikih stanica dva genetski i epigenetski potpuno odvojena entiteta, no za takvo mišljenje potrebna su dodatna istraživanja u ovome području ${ }^{9}$.

Agresivna terapija koju čini kombinacija kirurškog uklanjanja, radioterapije i kemoterapije opravdana je u PPTID-a visokog gradusa, ali upitno je kolika je korist radioterapije nakon totalne kirurške resekcije tumora $u$ tumora nižeg gradusa ${ }^{1,12}$. U slučaju PPTID-a gradusa II petogodišnje preživljenje iznosi $74 \%$, a u slučaju PPTID-a gradusa III ono iznosi $39 \%{ }^{11}$. Dok PPTID gradus II recidivira pretežno u području pinealne regije, PPTID gradus III može se javiti i u drugim dijelovima središnjeg živčanog sustava. Negativni prognostički čimbenici u ovih tumora jesu: metastaze u trenutku postavljanja dijagnoze, visoki patohistološki gradus (Ki-67 > 6\%, prisutnost nekroze) i subtotalna resekcija tumora. Pozitivitet na neurofilamentna bojenja povezan je s boljom progno$z^{13}$. Pojedina znanstvena istraživanja pokazuju da se relaps javlja u 56 \% PPTID-a visokog gradusa i u 26 \% PPTID-a niskog gradusa. Rasap cerebrospinalnim likvorom prisutan je u $36 \%$ tumora visokog gradusa i u $7 \%$ tumora niskog gradusa. Optimalni kirurški pristup, radioterapija i kemoterapija omogućavaju potencijalno duže preživljenje. Medijan preživljenja bez relapsa u određenim znanstvenim istraživanjima iznosio je 73 mjeseca, a ukupno preživljenje 94 mjeseca. Preživljenje nije bilo drastično lošije ni u slučaju recidiviranja tumora ${ }^{14}$.

Prethodni neuspjesi u predviđanju njihova ponašanja temelje se na nedostatku histoloških kriterija kojima se ovi tumori mogu morfološki odijeliti ${ }^{10}$.

Mehanizam kojim nastaju tumori u području pinealne žlijezde još je uvijek nepoznat. Pretpostavlja se da stres endoplazmatskog retikuluma (ER), koji je udružen s njegovim povećanjem, ima određenu ulogu u karcinogenezi tumora parenhima pinealne žlijezde ${ }^{15-18}$. Nadalje, s obzirom na to da tumori pinealne žlijezde zadržavaju sposobnost lučenja melatonina, pretpostavlja se da bi upravo taj hormon mogao imati bitnu ulogu u nastanku tih tumora ${ }^{19}$. Poznato je da melatonin inducira antioksidativne mehanizme i sudjeluje u eliminaciji reaktivnih kisikovih spojeva, što ide u prilog hipotezi o oksidativnom stresu kao precipitirajućem čimbeniku u nastanku tumora. Brojni literaturni podaci objašnjavaju korelaciju melatonina i povišenog rizika za razvoj šećerne bolesti tipa 2 i pretilosti te različitih novotvorina poput tumora dojke uslijed poremećaja u cirkadijanom ritmu ${ }^{20-24}$. Smatra se da melatonin modulira tumorsku inicijaciju, promociju i progresiju te ima utjecaj na staničnu proliferaciju, sintezu DNA-a, staničnu smrt, prolaženje kroz stanični ciklus, mehanizme oštećenja i popravka DNA-a, tumorsupresorske aktivnosti i invaziju tumorskim stanicama $^{25-28}$. U literaturi je opisano da melatonin u fiziološkim noćnim koncentracijama izravno inhibira sintezu tumorskog DNA-a i rast tumora supresijom uptakea linoleinske kiseline ovisnog o cAMP-u i njezinog metabolizma ${ }^{29-30}$. Literaturni podaci o citogenetičkoj podlozi PPTID-a podudaraju se s promjenama uočenima u pineoblastomima. Pomoću polimerazne lančane reakcije $u$ realnom vremenu (engl. real time polymerase chain reaction, RT-PCR) u PPTID visokog gradusa pronađena je snažna ekspresija gena PRAME, CD24, POU4F2 i HOXD13 ${ }^{31}$. U tumora višeg gradusa uočene su i promjene na 12 . i 22. kromosomu ${ }^{8}$. Potrebna su daljnja molekularna i citogenetička istraživanja o potencijalnom mehanizmu karcinogeneze parenhimnih tumora pinealne žlijezde.

\section{ZAKLJUČCI}

U ovom prikazu slučaja želi se istaknuti značaj prepoznavanja pinealnog parenhimnog tumora intermedijarnog stupnja diferencijacije kao rijetkog tumora središnjeg živčanog sustava koji često patologu predstavlja dijagnostički izazov zbog sličnosti s ostalim tumorima parenhima pinealne žlijezde. Jedino ispravno postavljena patohistološka dijagnoza može dovesti do odgovarajućeg izbora terapije $\mathrm{i}$ ispravnog kliničkog pristupa pacijentu $\mathrm{s}$ ovim tumorom. Potrebna su daljnja istraživanja kako bi se analizirala patofiziološka osnova nastanka svih tumora pinealne žlijezde s naglaskom na 
potencijalno lakše razlučivanje graničnog entiteta poput PPTID-a od pineocitoma i pineoblastoma. Daljnja molekularna istraživanja bila bi korisna patologu u postavljanju standarda i izradi smjernica koje bi pomogle u postavljanju točne dijagnoze.

Izjava o sukobu interesa: autori izjavljuju da ne postoji sukob interesa.

\section{LITERATURA}

1. Senft C, Raabe A, Hattingen E, Sommerlad D, Seifert V, Franz K. Pineal parenchymal tumor of intermediate differentiation: diagnostic pitfalls and discussion of treatment options of a rare tumor entity. Neurosurg Rev 2008;31:231-6.

2. Louis DN, Ohgaki H, Wiestler OD, Cavenee WK. WHO Classification of Tumours of the Central Nervous System. $4^{\text {th }}$ edition. Lyon: International Agency for Research on Cancer 2016;169-82.

3. Smith AB, Rushing EJ, Smirniotopoulos JG. From the archives of the AFIP: lesions of the pineal region: radiologicpathologic correlation. Radiographics 2010;30:2001-20.

4. Han SJ, Clark AJ, Ivan ME, Parsa AT, Perry A. Pathology of pineal parenchymal tumors. Neurosurg Clin N Am 2011;22:335-40.

5. Kakigi T, Okada T, Kanagaki M, Yamamoto A, Fushimi Y, Sakamoto $R$ et al. Quantitative imaging values of CT, $M R$, and FDG-PET to differentiate pineal parenchymal tumors and germinomas: are they useful? Neuroradiology 2014;56:297-303.

6. Smirniotopoulos JG, Rushing EJ, Mena H. Pineal region masses: differential diagnosis. Radiographics 1992;12:577-96.

7. Dahiya S, Perry A. Pineal Tumors. Lippincott Williams \& Wilkins: Adv Anat Pathol 2010;17:419-27.

8. Rickert $\mathrm{CH}$, Simon R, Bergmann M, Dockhorn-Dworniczak B, Paulus W. Comparative genomic hybridization in pineal parenchymal tumors. Genes Chromosomes Cancer 2001;30:99-104.

9. Raleigh DR, Solomon DA, Lloyd SA, Lazar A, Garcia MA, Sneed PK et al. Histopathologic review of pineal parenchymal tumors identifies novel morphologic subtypes and prognostic factors for outcome. Neuro Oncol 2017; 19:78-88.

10. Schild SE, Scheithauer BW, Schomberg PJ, Hook CC, Kelly PJ, Frick L et al. Pineal parenchymal tumors. Clinical, pathologic, and therapeutic aspects. Cancer 1993; 72:870-80.

11. Fauchon F, Jouvet $A$, Paquis $P$, Saint-Pierre $G$, Mottolese $C$, Ben Hassel $M$ et al. Parenchymal pineal tumors: a clinicopathological study of 76 cases. Int J Radiat Oncol Biol Phys 2000;46:959-68.

12. Anan M, Ishii K, Nakamura T, Yamashita M, Katayama S, Sainoo $M$ et al. Postoperative adjuvant treatment for pineal parenchymal tumors of intermediate differentiation. J Clin Neurosci 2006;12:965-8.

13. Lutterbach J, Fauchon F, Schild SE, Chang SM, Pagenstecher A, Volk B et al. Malignant pineal parenchymal tumors in adult patients: patterns of care and prognostic factors. Neurosurgery 2002;51:44-56.

14. Watanabe T, Mizowaki T, Arakawa Y, lizuka Y, Ogura K, Sakanaka $\mathrm{K}$ et al. Pineal parenchymal tumor of interme- diate differentiation: Treatment outcomes of five cases. Molecular and Clinical Oncology 2014;2:197-202.

15. Jouvet $A$, Fauchon $F$, Liberski P, Saint-Pierre G, DidierBazes $M$, Heitzmann $A$ et al. Papillary tumor of the pineal region. The American Journal of Surgical Pathology. 2003;27:505-12.

16. Kline KT, Damjanov I, Katz SM, Schmidek H. Pineoblastoma: an electron microscopic study. Cancer 1979;44: 1692-9.

17. Tabuchi K, Yamada O, Nishimoto A. The ultrastructure of pinealomas. Act Neuropathologica 1973;24:117-27.

18. Fernández A, Ordóñez R, Reiter RJ, González-Gallego J, Mauriz JL. Melatonin and endoplasmic reticulum stress: relation to autophagy and apoptosis. Journal of Pineal Research 2015;59:292-307.19.

19. Fèvre-Montange $M$, Champier J, Szathmari $A$, Brisson $C$, Reboul A, Mottolese $C$ et al. Histological features and expression of enzymes implicated in melatonin synthesis in pineal parenchymal tumours and in cultured tumoural pineal cells. Neuropathology and Applied Neurobiology 2008;34:296-305.

20. Golombek DA, Rosenstein RE. Physiology of circadian entrainment. Physiol Rev 2010;90:1063-102.

21. Bass J, Takahashi JS. Circadian integration of metabolism and energetics. Science 2010;330:1349-54.

22. Reiter RJ, Tan DX, Korkmaz A, Ma S. Obesity and metabolic syndrome: Association with chronodisruption, sleep deprivation, and melatonin suppression. Ann Med 2012;44:564-77

23. Stevens RG. Circadian disruption and breast cancer: from melatonin to clock genes. Epidemiology 2005;16: 254-8.

24. Stevens RG. Light-at-night, circadian disruption and breast cancer: assessment of existing evidence. Int J Epidemiol 2009;38:963-70.

25. Hrushesky WJ. The temporal organization of life: the impact of multifrequency non-linear biologic time structure upon the host-cancer balance. Jpn J Clin Oncol 2000;30:529-33.

26. Hrushesky WJ. Tumor chronobiology. J Control Release 2001;74:27.

27. Canaple L, Kakizawa T, Laudet V. The days and nights of cancer cells. Cancer Res 2003;63:7545-52.

28. Blask DE, Hill SM, Dauchy RT, Xiang S, Yuan L, Duplessis $T$ et al. Circadian regulation of molecular, dietary, and metabolic signaling mechanisms of human breast cancer growth by the nocturnal melatonin signal and the consequences of its disruption by light at night. J Pineal Res 2011;51:259-69.

29. Blask DE, Sauer LA, Dauchy RT, Holowachuk EW, Ruhoff MS, Kopff HS. Melatonin inhibition of cancer growth in vivo involves suppression of tumor fatty acid metabolism via melatonin receptor-mediated signal transduction events. Cancer Res 1999;59:4693-701.

30. Blask DE, Brainard GC, Dauchy RT, Hanifin JP, Davidson LK, Krause JA et al. Melatonin-depleted blood from premenopausal women exposed to light at night stimulates growth of human breast cancer xenografts in nude rats. Cancer Res 2005;65:11174-84.

31. Fèvre-Montange $M$, Champier J, Szathmari $A$, Wiernickx A, Mottolese C, Guyotat J et al. Microarray analysis reveals differential gene expression patterns in tumors of the pineal region. J Neuropathol Exp Neurol 2006;65:675-84. 